\title{
Market or Morality - Follow an Unethical Action for the Management?
}

\author{
Lars Engstfeld ${ }^{1}$, Martin ${\text { Užík }{ }^{2, *} \text {, and Sebastian Block }}^{3}$ \\ ${ }^{1}$ Lars Engstfeld is a graduate economist from the University of Wuppertal and works as a controller for \\ the OBI Group Holding SE \& Co. KGaA \\ ${ }^{2}$ Prof. Dr. Martin Užík earned his PhD and Habilitation at the University of Wuppertal and holds a \\ professorship in the field of finance at the Berlin School of Economics and Law \\ ${ }^{3}$ Sebastian Block LL.M. is a doctoral student at the Technical University Košice and works as a research \\ associate at the Berlin School of Economics and Law
}

\begin{abstract}
.
Research background: With countless standards and rankings for moral behavior of large companies on one side and corporate scandals of immoral actions on the other, the question arises whether it is important at all for stock corporations to keep a clean slate or whether their value might not even be affected by emerging scandals.

Purpose of the article: This paper analyzes whether and how the stock market reacts to newly published news about immoral behavior by stock corporations. It shows the reactions of stock prices to morality scandals for 39 different companies that have all been exposed for immoral behavior.

Methods: After establishing a standard time window around the event day of the emerging news, the stock reaction is analyzed by estimating the selected companies' share prices based on their past and then comparing the estimated values to the actual values on and after the event day.

Findings \& Value added: While the overall finding is that stock prices do not react to their companies' scandals with statistical significance, it is shown that the stock prices of smaller companies are affected more than those of the bigger example companies. It can therefore still be recommended for companies to build a good reputation by showing responsible behavior.
\end{abstract}

Keywords: portfolio; morality; ethics; investment

JEL Classification: $G 11 ; G 40$

\footnotetext{
*Corresponding author: martin.uzik@hwr-berlin.de
} 


\section{Introduction}

"Moral brings profit"[1] is the title of the German magazine "Wirtschaftswoche" on the cover of its $38^{\text {th }}$ issue and it shows just how relevant the topic of ethics is at present. And indeed, the market for ethical, social, and "green" investments is developing positively. More and more listed companies are incorporating sustainability ${ }^{1}$ criteria[2] into their corporate policies in order to influence investors' investment decisions.[3] It is surprising to learn that morality can even be used to earn money, because this term is still associated with overpriced eco-products or image-damaging protest actions by non-governmental organizations ${ }^{2}$ (NGOs). But there is more to it than that. In the meantime, countless standards, rating agencies, rankings, and awards have been established to make entrepreneurial activities more transparent. At the same time, corporate scandals call for more corporate social responsibility. Board members increase their salaries while at the same time releasing thousands of employees. Additionally, counterfeit balance sheets shake confidence in the companies. Numerous other examples could be cited which reinforce the desire for a morality which respects the profit principle. On the other hand, there has been increasing deregulation in recent years, as can be seen from the liberalization of the energy, telecommunications, and mail services markets. However, this development seems to exacerbate the problems mentioned above. More market means more entrepreneurial freedom, which could be used to ruthlessly generate higher profits at the expense of the general public. In this context, critics of globalization in particular denounce the misuse of room for manoeuvre by management.[4] It is often disregarded that the market can also serve the welfare of all if it is not limited by bureaucratic regulations. In this context, the need for independent (corporate) ethics is denied, as the market automatically disciplines its participants to behave correctly.[5]

This makes it all too clear that the market on the one hand and morality on the other form a strongly polarizing pair of terms. Nevertheless, powerful arguments can be put forward for both variants which show that a socially optimal result can be achieved in two ways. Thus, the question arises not only for consumers, suppliers, or the press, but also for companies themselves: market or morality?

\subsection{The market}

If economists and managers are to be believed, everything changes for the better if the market is left to its own devices and follows a free course. At any rate, this opinion can be found in numerous textbooks on economics, the authors of which define the market as an "informal institution for handling the allocation process".[6] The most appropriate and fair form for this is the perfect market, which, however, only functions under very specific, idealized conditions: an infinite number of market participants on both sides, no objective, temporal or personal preferences, the possibility of free market entry or exit, and complete information about the conditions under which other exchange partners are prepared to enter into transactions. In a perfect market, therefore, all the above conditions must be met. Only then can the market develop its full potential and perform the following functions:

- Allocation function: most efficient possible use of production factors

- Pricing and coordination function: achieving a balance between supply and demand

\footnotetext{
${ }^{1}$ Sustainability in this context means "satisfying the needs of the present without compromising the ability of future generations to meet their own needs".

${ }^{2}$ For example, Greenpeace's 1995 Brent Spa campaign, which prevented the sinking of the disused oil loading platform.
} 
- Pension formation as the difference between the producer's willingness to pay or lower the price limit on the one hand and the market price on the other (welfare)

- Promoting innovation: identifying inefficient production processes to avoid costs and competitive pressures

"[E]very individual ... generally, indeed, neither intends to promote the public interest, nor knows how much he is promoting it. By preferring the support of domestic to that of foreign industry he intends only his own security; and by directing that industry in such a manner as its produce may be of the greatest value, he intends only his own gain, and he is in this, as in many other cases, led by an invisible hand to promote an end which was no part of his intention."'[7]

What the founding father of the national economy, the Scottish moral philosopher Adam Smith, formulated with these sentences in his famous work "The Wealth of Nations" earned him much admiration and recognition: Not through altruism, but with an orientation towards self-interest, each individual promotes public interests without intending it themselves. Their actions are efficiently guided as if by an "invisible hand". Smith sees the reason for the connection between egoism and efficiency in the fact that in the exchange of goods, both sides profit from the transaction. Both parties try to obtain the largest possible share of the exchange profit without aiming at overall economic efficiency. Nevertheless, this results in an outcome that neither of the two intended.[8]

Many assumptions are made in theory, but they are rarely found in reality. For example, all of the exchange partners are not always fully aware of their exchange options, or there are not enough parties so that monopoly-like structures emerge. For this reason, Kirstein and Schmidtchen's research project is concerned with the question of whether, and if so, how the "invisible hand" functions under weaker assumptions. As early as the end of 1998, German students from Saarland University took part in a classroom experiment that empirically explained the occurrence of a market price. The participants in the experiment were asked to deal with a good that had deliberately not been specified. In this way, it was ruled out that personal preferences or dislikes could have an unwanted effect on the transactions. [8] The exchange results show that the competitive process in the experiment has led to the use of decentralized knowledge and to the control of actions in a way that would otherwise only have been possible for an omniscient central authority.[8] Adam Smith's thesis about the functioning of the "invisible hand" seems to be confirmed by this test, because the number of traded units of the good as well as the final prices achieved are very close to the theoretically determined equilibrium values. This result thus corresponds to that of Vernon Smith, who formulated in his "Hayek hypothesis": "Strict privacy together with trading rules of a market institution are sufficient to produce ... near $100 \%$ efficiency."'[9]

\subsection{Morality}

In February 2005, Deutsche Bank announced that it intended to lay off 6,400 employees in spite of profits running into billions. The wave of redundancies should help to achieve an ambitious goal, namely to increase profit before tax by almost a quarter. This is intended to raise the return on equity to up to $25 \%$ in order not to lose the connection to comparable institutions and to ward off foreign takeover attempts. This news caused sharp criticism, not least from the unions. Jürgen Peters, chairman of the German union IG-Metall, described the bank's behavior as "intolerable and irresponsible", which stimulated a debate on morality and ethics in the German economy.

Many fear that the application of market economy principles is to blame for this development and that it endangers the cohesion of society. So, it is not surprising that the market economy is perceived by many as inhumane, immoral, and unjust.[10] The high approval of the criticism of capitalism ("grasshopper debate") in spring of 2005 shows that 
citizens no longer approve of the purely profit-oriented behavior of companies. This is accompanied by increased doubts about the value of freedom as an essential element of the market economy. While in 1990 , over $60 \%$ of Germans were still convinced that freedom was more important than equality, at the end of 2003, only just under $50 \%$ agreed with this statement.[11]

The reasons for the skepticism towards the free-market liberal system are seen, among other things, in the increasing internationalization of the economy and the associated increased dynamics of social processes. But the growing anonymization of society and the intensification of the division of labor also mean that people are increasingly looking for lasting values and norms.[10]

In recent years, more and more companies and their shareholders have suffered considerable damage as a result of corporate leaders failing to comply with official requirements or legal standards. The press regularly reports on billions in fines, lengthy court proceedings, criminal convictions of board members, and tarnished corporate reputations. These events have led to a sharp decline in investor and consumer confidence in the reliability of companies.

Obviously, for this reason, more and more companies are beginning to question the quality of their management systems and are trying to gain a competitive advantage from corporate values. The computer manufacturer Dell Computer Inc., for example, publishes a statement on its corporate values on its homepage. "The Soul of Dell" conveys to both employees and customers the five corporate values of customer loyalty, teamwork, open communication, and effective relationships with customers, suppliers, and partners, responsible action in global markets, and the passion to win.[12] The CEO of the successful technology and service company Xerox, Anne Mulcahy, also states: "Corporate values helped save Xerox during the worst crisis in our history."'[13] And finally, Citigroup CEO Charles Prince admits in the wake of a banking scandal in Japan: "All the talk about culture and values, I think, is exactly right."[14] In this respect, the question arises as to whether there is indeed a connection between the pursuit of and adherence to values, business practices based on sustainability criteria, and economic success in business practice.

\section{Methodology - Empirical analysis of capital market reactions to the discovery of "immoral" actions by companies}

Numerous studies show that the long-term performance of companies can be positively influenced by ethical and socially responsible actions. They also showed that sustainable management can help improve the return on equities and bonds and thus maintain a double dividend in the form of return and a clear conscience.

On the basis of these findings, however, the question arises as to whether the capital market is punishing those companies that are known to have defied moral norms. In cases where the moral infringements coincide with the legal infringements, a mechanism is in place to alert investors of a possible impairment of their equity assets. Section 15 paragraph 1 $\mathrm{WpHG}$ requires domestic issuers of financial instruments to immediately publish new facts that have occurred in their sphere of activity, are not yet publicly known, and are likely to significantly influence the market price of the admitted securities.

In the past, renowned researchers have dealt with the information relevance of corporate news for investors and the importance of information for pricing on the capital market. However, most of these investigations relate solely to the processing of information on ad hoc notifications. As early as 1969, Fama et al.[15] investigated and confirmed the signal effect of splits on US markets. Miller/Modigliani[16] showed in 1961 that reports of dividends have no influence in perfect markets. For the German market, Coenenberg[17] in particular was able to demonstrate significant share price reactions to profit reports. 
In this context, this empirical analysis is intended to examine whether the disclosure of corporate decisions, which are generally considered immoral by society, is recognized by investors as valuation-relevant information and processed in the share price. On the one hand, the differentiation from existing studies lies in the fact that "immoral" corporate actions are considered for the first time. On the other hand, both ad hoc announcements and other sources of information such as press and television reports, study results, and publications of the German Schutzgemeinschaft der Kapitalanleger ( $\mathrm{SdK}$ ) are used. The conclusion is examined in the context of an event study on the basis of course reactions in the temporal environment in which the information becomes known.

\subsection{Definition of "immoral" actions}

In order to be able to make a reliable selection of immoral companies, it is first necessary to carry out an exact definition of "immoral" actions of companies. The assessment of what exactly is moral or immoral, however, is subject to a strongly subjective influence. In addition, the notions of morality vary greatly depending on the period or region. The following definition is therefore used in the context of this investigation: The Latin term "morality" (lat. mos, pl. mores: custom) describes the totality of norms and values that actually determine, or at least should determine, the actions of human beings.[18] If individuals violate these rules, they usually react with feelings of guilt. Thus, the prevailing morality of a society or culture pretends "what is generally considered at a given time in a given society as action, condition or attitude good and desirable, or evil and forbidden".[19] Morality becomes visible above all in norms of action such as rules, regulations, and guiding principles, but also in standards of value, concepts of meaning, or role models.[19] So, what is considered ethical or not ethical varies from person to person and is subject to subjective assessments. Thus, fraud against an anonymous third party (e.g. a state, insurance company, or large corporation) is considered less reprehensible by people than, for example, the theft of a newspaper. On the other hand, responsible and careful handling of resources as well as social interaction with employees, customers, and suppliers are considered desirable and thus morally necessary.

A clear separation between legal and purely moral misconduct is therefore not possible. Thus, in the present study, those actions are considered immoral which are generally considered by society, the press, and other interested parties to be the same, and which are brought to the attention of the public through protests and reports. These actions include, among others, the obviously wasteful handling of shareholder contributions (Borussia Dortmund), the deliberate acceptance of poisoning and deaths among farm workers in developing countries (Bayer, Syngenta, Advanta) or the sale of secret numbers to information services (Telekom).

\subsection{Research method}

On the basis of the above definition, a search for morally conspicuous companies was carried out. The internet, online archives of major daily newspapers, ${ }^{3}$ numerous news portals, ${ }^{4}$ television reports, Wikipedia, and ad hoc announcements ${ }^{5}$ were searched for reports of stock market scandals. In this way, companies could be identified which are not only small companies or offshoots of the New Market. Well-known DAX companies such as Bayer, Deutsche Bank, Siemens, and Adidas complete the list of immoral companies.

\footnotetext{
${ }^{3}$ For example FAZ, Handelsblatt, or Die Zeit

${ }^{4}$ For example Heise-Newsticker, aktiencheck.de, or ad-hoc-news.de

${ }^{5}$ For example on www.gdap.de
} 
Table 1. List of immoral companies. (Source: Own representation).

\begin{tabular}{|c|c|c|c|c|}
\hline No. & Company & Incident & $\begin{array}{c}\text { Notification } \\
\text { Type }\end{array}$ & Date \\
\hline 1 & ADIDAS (XET) & bribery & item & $09 / 28 / 2017$ \\
\hline 2 & BARCLAYS & $\begin{array}{l}\text { fined for attempting to } \\
\text { manipulate LIBOR }\end{array}$ & press release & $06 / 27 / 2012$ \\
\hline 3 & BAYER (XET) & birth control pill scandal & press release & $12 / 16 / 2015$ \\
\hline 4 & BNP PARIBAS & money laundering & news & $04 / 30 / 2014$ \\
\hline 5 & $\mathrm{BP}$ & oil spill after explosion & news & $04 / 20 / 2010$ \\
\hline 6 & $\begin{array}{c}\text { BRITISH AMERICAN } \\
\text { TOBACCO }\end{array}$ & fraud & TV investigation & $11 / 30 / 2015$ \\
\hline 7 & THANK YOU BANK & money laundering & report & $09 / 19 / 2018$ \\
\hline 8 & GERMAN POST (XET) & money laundering & item & $11 / 19 / 2018$ \\
\hline 9 & $\begin{array}{l}\text { GERMAN TELEKOM } \\
(\mathrm{XET})\end{array}$ & surveillance affair & item & $05 / 25 / 2008$ \\
\hline 10 & $\begin{array}{l}\text { DEUTSCHE WOHNEN } \\
\text { (XET) BR. SHS. }\end{array}$ & bad management & item & $04 / 04 / 2018$ \\
\hline 11 & EASYJET & pilot scandal & news & $08 / 23 / 2018$ \\
\hline 12 & $\begin{array}{l}\text { FIAT CHRYSLER } \\
\text { AUTOMOBILES }\end{array}$ & diesel scandal & item & $01 / 13 / 2017$ \\
\hline 13 & GLAXOSMITHCLINE & bribery & item & $05 / 14 / 2014$ \\
\hline 14 & HSBC HOLDINGS & $\begin{array}{l}\text { bank helped clients with tax } \\
\text { evasion }\end{array}$ & news & $02 / 08 / 2015$ \\
\hline 15 & INDIVIOR & $\begin{array}{l}\text { accused of illegally marketing } \\
\text { opioids to drug addicts }\end{array}$ & press release & $04 / 09 / 2019$ \\
\hline 16 & NEX GROUP & $\begin{array}{l}\text { helped manipulate a financial } \\
\text { benchmark used to calculate a } \\
\text { range of interest-rate products }\end{array}$ & item & $09 / 18 / 2018$ \\
\hline 17 & NOKIAN RENKAAT & manipulated tire tests & item & $02 / 26 / 2016$ \\
\hline 18 & NORDEA BANK & $\begin{array}{l}\text { allegation involved in money } \\
\text { laundering }\end{array}$ & item & $10 / 16 / 2018$ \\
\hline 19 & NORSK HYDRO & $\begin{array}{l}\text { admitted to polluting water in } \\
\text { Brazil which they denied } \\
\text { beforehand }\end{array}$ & press release & $03 / 19 / 2018$ \\
\hline 20 & NOVARTIS 'R' & allegation of bribery & item & $01 / 20 / 2017$ \\
\hline 21 & $\begin{array}{l}\text { RAIFFEISEN BANK } \\
\text { INTL. }\end{array}$ & money laundering & item & $03 / 04 / 2019$ \\
\hline 22 & EDGE CITY & treatment of employees & TV report & $11 / 24 / 2011$ \\
\hline 23 & RENAULT & CEO fraud & press release & $11 / 19 / 2018$ \\
\hline 24 & RHEINMETALL (XET) & bribery & item & $01 / 26 / 2014$ \\
\hline 25 & $\begin{array}{c}\text { ROLLS-ROYCE } \\
\text { HOLDINGS }\end{array}$ & bribery and corruption & report & $12 / 06 / 2012$ \\
\hline 26 & $\begin{array}{l}\text { ROYAL BANK OF SCTL. } \\
\text { GP. }\end{array}$ & $\begin{array}{c}\$ 4.9 \text { billion fine for mis selling } \\
\text { mortgages }\end{array}$ & $\begin{array}{c}\text { financial fraud } \\
\text { publication }\end{array}$ & $08 / 14 / 2018$ \\
\hline 27 & ROYAL MAIL & $\begin{array}{c}\text { postal service broke } \\
\text { competition law }\end{array}$ & $\begin{array}{l}\text { investigation by } \\
\text { other company }\end{array}$ & $08 / 14 / 2018$ \\
\hline 28 & $\begin{array}{l}\text { RSA INSURANCE } \\
\text { GROUP }\end{array}$ & manipulating reserve estimates & public statement & $12 / 18 / 2018$ \\
\hline 29 & SAFRAN & bribery & news article & $09 / 05 / 2012$ \\
\hline 30 & SIEMENS (XET) & bribery & $\begin{array}{l}\text { criminal fraud } \\
\text { publication }\end{array}$ & $12 / 15 / 2008$ \\
\hline 31 & $\begin{array}{c}\text { STANDARD } \\
\text { CHARTERED } \\
\end{array}$ & $\begin{array}{l}\text { violating U.S. sanctions against } \\
\text { Iran, Sudan, and more }\end{array}$ & item & $12 / 10 / 2012$ \\
\hline 32 & $\begin{array}{l}\text { STEINHOFF INTL. HDG. } \\
\text { (XET) }\end{array}$ & $\begin{array}{c}\text { overstated profits and assets by } \\
\text { nearly } \$ 12 \text { billion }\end{array}$ & press release & $12 / 05 / 2017$ \\
\hline
\end{tabular}




\begin{tabular}{|c|c|c|c|c|}
\hline 33 & SWEDBANK 'A' & money laundering & press release & $03 / 22 / 2019$ \\
\hline 34 & TAYLOR WIMPEY & $\begin{array}{c}\text { new-built leasehold properties } \\
\text { left nearly worthless owing to } \\
\text { spiraling charges }\end{array}$ & $\begin{array}{c}\text { news outlet } \\
\text { investigation }\end{array}$ & $11 / 05 / 2016$ \\
\hline 35 & TOTAL & $\begin{array}{c}\text { bribery in UN's Iraq Aid } \\
\text { Program }\end{array}$ & item & $02 / 26 / 2016$ \\
\hline 36 & UBS GROUP & $\begin{array}{c}€ 3.7 \text { billion fine for money } \\
\text { laundering/tax evasion }\end{array}$ & press release & $02 / 20 / 2019$ \\
\hline 37 & $\begin{array}{c}\text { VOLKSWAGEN PREF. } \\
\text { (XET) }\end{array}$ & diesel scandal & $\begin{array}{c}\text { notice of } \\
\text { violation, report }\end{array}$ & $09 / 18 / 2015$ \\
\hline 38 & YARA INTERNATIONAL & bribery & press release & $01 / 15 / 2014$ \\
\hline 39 & $\begin{array}{c}\text { ZURICH INSURANCE } \\
\text { GROUP }\end{array}$ & $\begin{array}{c}\text { VW diesel scandal D\&O } \\
\text { insurance }\end{array}$ & item & $02 / 10 / 2015$ \\
\hline
\end{tabular}

When selecting the relevant companies, it must be taken into account that the companies operate in the legal form of a stock corporation or a partnership limited by shares (Kommanditgesellschaft auf Aktien) and that a stock market price is determined for them on a stock exchange. However, given the difficulties in selecting suitable companies, no further restrictive criteria can be laid down. Accordingly, no restrictions are made with regard to index membership, registered office, or company size, so that a portfolio of 39 companies can be obtained in this way.

In order to determine the decision relevance of newly emerging information, it is necessary to determine the exact time of publication.[20] This study examines the abnormal returns on the day of the event, i.e. the day the report is published. However, a reliable interpretation of these results is only possible if the event day is precisely identified. For this reason, several sources were used to obtain information. By comparing the publication dates, it was possible to ensure that the earliest publication date and thus the event date were reliably determined. If a publication takes place at the weekend or on a public holiday, the next possible stock exchange trading day is assigned to the event day.

In this context, however, there is the possibility that capital market reactions can be observed not only on the day of the event itself, but also a few days before or after the event. In order to cover the entire information effect of the reports, the research period must be extended to the trading days surrounding the event day. It seems advisable to choose an event period that is as long as possible so that the entire information processing activity can be observed. This procedure becomes problematic if, within this period, other information becomes known that could influence the share price. If, for example, a company report is preceded by the publication of its annual financial statements, the capital market reactions that occur cannot be clearly attributed to the content of the report. In the present analysis, a total research period of 41 trading days is chosen. The day of the publication of the information is called $t_{0}$ in the further process. The research period starts 20 days before $t_{0}$ in D 20 before and ends 20 days after $t_{0}$ in D 20. The choice of the event period, however, does not prevent the recording of any anticipatory effects. On the other hand, this ensures that even delayed adjustment processes to the messages can be fully monitored.

In the next step, the capital market data required for an empirical analysis are used. These include the daily closing prices of the 39 companies surveyed on, before and after the day of the event. Due to a lack of data, 10 companies had to be cleaned out. On the other hand, the capital market data of the corresponding indices are also required for the period under review. They are used later to calculate the market return. These data are obtained with the help of the online database of Handelsblatt.de and adjusted for other payments such as share splits, dividend payments, and capital increases. The data series of the security prices goes back to 500 days before the research period and forms the estimation period. This estimation period is considered below to be representative of the development of the return on securities during 
the event period. It is also adjusted for the trading days on which either the price of the security or the price of the index is available in the event period. For each eliminated value, an older value moves up, so that there are always 500 market values before the period under review.

Now that data collection has been completed with this step, this event study examines price reactions to the publication of corporate news about immoral behavior. The focus here is on whether an abnormal return, i.e. a return that deviates from expectations, is achieved on the day of the event. In order to show that a price reaction on the event day is directly attributable to the publication of an announcement, the yield that would have been expected if the announcement had not occurred in the market is first estimated. The difference between the expected return and the return actually realized on the market is understood as an abnormal return. It is regarded as an indicator of the information effect of the underlying event[21] and can be presented as follows:

$$
A R_{\mathrm{i}, \mathrm{t}}=r_{\mathrm{i}, \mathrm{t}}-E\left(r_{\mathrm{i}, \mathrm{t}}\right)
$$

with:

$A R_{\mathrm{i}, \mathrm{t}}$ : $\quad$ Abnormal yield of security $\mathrm{i}$ in the period from $\mathrm{t}_{-1}$ to $\mathrm{t}$

$r_{\mathrm{i}, \mathrm{t}}$ : $\quad$ Observed return on security $\mathrm{i}$ in the period from $\mathrm{t}_{-1}$ to $\mathrm{t}$

$E\left(r_{\mathrm{i}, \mathrm{t}}\right)$ : $\quad$ Expected return on security $\mathrm{i}$ in the period from $\mathrm{t}_{-1}$ to $\mathrm{t}$

The expected return can be calculated using various methods and models. ${ }^{6}$ While other models do not take into account security-specific influences or assume constant return expectations, the market model used here calculates the expected return using model parameters derived from a linear regression model:

$$
E\left(r_{\mathrm{i}, \mathrm{t}}\right)=\alpha_{\mathrm{i}}+\beta_{\mathrm{i}} \times r_{\mathrm{m}, \mathrm{t}}+\varepsilon_{\mathrm{i}, \mathrm{t}}
$$

with:

$\alpha_{\mathrm{i}}$ : $\quad$ Component of the yield of the security $\mathrm{i}$ that is independent of the market yield

$\beta_{\mathrm{i}}$ : $\quad$ Measure of the influence of the market yield on the yield of the security $\mathrm{i}$

$\varepsilon_{\mathrm{i}, \mathrm{t}}$ : $\quad$ Disturbance date of security i at time $\mathrm{t}$

$r_{\mathrm{m}, \mathrm{t}}: \quad$ Observed market return (return of index $\mathrm{i}$ at time $\mathrm{t}$ )

A linear correlation between the securities yield and the market yield is assumed.[22] The expressions of the dependent variables $r_{i, t}$ are explained by the expressions of the independent variables $r_{m, t}$. $\alpha$ and $\beta$ are the regression coefficients resulting from the estimation period, which represent the estimation of the true coefficient of the population. They were determined using the linear regression model for the estimation period [-500;-21]. This period ends one day before the start of the event period in order to avoid an overlap of the data. Finally, $\varepsilon_{i, t}$ is the so-called disturbance variable. It describes the deviations between the value declared $r_{m, t}$ by the independent variable and the realized value $r_{i, t .}$. 23]

In addition to calculating the expected returns using the market model, the price changes of the securities as well as those of the indices must also be determined on a daily basis. It is advisable to use relative returns instead of absolute price changes, as this balances out level differences and makes the analysis data comparable. The continuous yield can then be calculated by logarithmizing the relative price developments:

${ }^{6}$ The best-known models include CAPM, the method of average adjusted returns, the method of market adjusted returns, and the market model. 


$$
r_{\mathrm{i}, \mathrm{t}}=\ln \left(\frac{P_{\mathrm{i}, \mathrm{t}}}{P_{\mathrm{i}, \mathrm{t}-1}}\right)=\ln \left(P_{\mathrm{i}, \mathrm{t}}\right)-\ln \left(P_{\mathrm{i}, \mathrm{t}-1}\right)
$$

with:

$r_{\mathrm{i}, \mathrm{t}}$ : Continuous yield on security/index $\mathrm{i}$ in the period from $\mathrm{t}_{-1}$ to $\mathrm{t}$

$P_{\mathrm{i}, \mathrm{t}}$ : $\quad$ Price of security/index $\mathrm{i}$ at the time point $\mathrm{t}$

The abnormal return attributable to the news publication is now the difference between the observed returns in the event period and the expected returns estimated using the market model:

$$
A R_{\mathrm{i}, \mathrm{t}}=r_{\mathrm{i}, \mathrm{t}}-\left(\hat{\alpha}_{\mathrm{i}}+\hat{\beta}_{\mathrm{i}} \times r_{\mathrm{m}, \mathrm{t}}\right)
$$

This shows that the abnormal return at the corresponding times of the event period corresponds exactly to the disturbance term of the market model.

In order to be able to finally make generally valid statements about the price reactions to the discovery of immoral actions, the abnormal returns determined for the respective event days are summarized. By aggregating the values, random estimation errors and unsystematic influencing factors can also be eliminated.[21] For this purpose, the average abnormal yields of $\mathrm{AAR}_{\mathrm{t}}$, the securities in question on a day of the event period, are determined:

$$
A A R_{\mathrm{t}}=\frac{1}{\mathrm{~N}} \sum_{\mathrm{i}=1}^{\mathrm{N}} A R_{\mathrm{i}, \mathrm{t}}
$$

In addition to the analysis of the average abnormal returns on a specific event day, the investigation also aims to consider a specific event period. For this purpose, the average abnormal returns determined are aggregated over a certain time window, for which the additive[15] as well as the multiplicative linkage of[24] the abnormal returns are available. Since the rising returns were calculated by logarithmic price changes, the additive link in the form of "cumulative average residuals" (CAR) is suitable due to their temporal additivity properties.[21] The CAR is calculated by cumulating the average daily abnormal returns over the period of the $\mathrm{AAR}_{t}$ event period:

$$
C_{-20 ; 20}=\sum_{\mathrm{t}=-20}^{20} A A R_{\mathrm{t}}
$$

Finally, the so-called single-sample t-test is used to check the statistical significance. It aims to determine the significance of the mean abnormal returns by relating the mean abnormal returns of the sample to its estimated standard deviation.[21] For this purpose, the null hypothesis to be refuted is $\mathrm{H}_{0}: \mu=\mu_{0}$, which assumes a non-existent deviation of the abnormal returns from zero. The alternative hypothesis $\mathrm{H}_{1}$ is therefore $\mathrm{H}_{1}: \mu \neq \mu_{0} . \mathrm{H}_{0}$ is then discarded for the test level $\alpha$ if the following applies:

$$
\sqrt{n} \times \frac{\left|A A R_{\mathrm{t}}-\mu_{0}\right|}{s\left(A R_{\mathrm{t}}\right)} \geq Z_{1-\alpha ; n-1}
$$

with:

$n: \quad \quad$ Number of securities in the sample

$A A R_{\mathrm{t}}: \quad$ Mean abnormal return at time $\mathrm{t}$

$s\left(A R_{\mathrm{t}}\right): \quad$ Standard deviation of abnormal returns at time $\mathrm{t}$

\section{Test results}

The results obtained show that on the day when the public first has the opportunity to learn of a company's immoral actions, an average abnormal daily return (AAR) of $-3.59 \%$ 
was achieved. In comparison, the AARs of the previous 20 trading days are considerably lower and are in an interval of -1.17 and $0.87 \%$ respectively. The AARs of the following 20 trading days are much more volatile and range between -2.62 and $1.2 \%$.

Table 2 shows the total average abnormal daily returns and the cumulative abnormal daily returns (CAR) for the period [-20;20]. In addition, the table provides information on the corresponding $t$ values and the number of positive or negative AARs on the respective days of the research period.

Table 2. One-Sample Test. Overview of periods and yields. (Source: Own representation).

\begin{tabular}{|c|c|c|c|c|c|c|}
\hline \multirow{3}{*}{ Days } & \multicolumn{6}{|c|}{ Test Value $=0$} \\
\hline & \multirow[t]{2}{*}{$\mathbf{t}$} & \multirow[t]{2}{*}{ df } & \multirow[t]{2}{*}{ Sig. (2-tailed) } & \multirow[t]{2}{*}{$\begin{array}{c}\text { Mean } \\
\text { Difference }\end{array}$} & \multicolumn{2}{|c|}{$\begin{array}{l}\text { 95\% Confidence } \\
\text { Interval of the } \\
\text { Difference }\end{array}$} \\
\hline & & & & & Lower & Upper \\
\hline D 20 before & -0.828 & 28 & 0.415 & -0.00363 & -0.0126 & 0.0053 \\
\hline D 19 before & -1.157 & 28 & 0.257 & -0.00611 & $\begin{array}{l}-0.0169 \\
\end{array}$ & 0.0047 \\
\hline D 18 before & 0.666 & 28 & 0.511 & 0.00259 & $\begin{array}{l}-0.0054 \\
\end{array}$ & 0.0105 \\
\hline D 17 before & 0.682 & 26 & 0.501 & 0.00316 & $\begin{array}{l}-0.0064 \\
\end{array}$ & 0.0127 \\
\hline D 16 before & 1.222 & 26 & 0.233 & 0.00875 & -0.0060 & 0.0235 \\
\hline D 15 before & -1.945 & 26 & 0.063 & -0.00794 & -0.0163 & 0.0005 \\
\hline D 14 before & 0.191 & 26 & 0.850 & 0.00068 & -0.0067 & 0.0080 \\
\hline D 13 before & 0.142 & 26 & 0.888 & 0.00045 & -0.0061 & 0.0070 \\
\hline D 12 before & -1.381 & 26 & 0.179 & -0.00554 & -0.0138 & 0.0027 \\
\hline D 11 before & 0.748 & 26 & 0.461 & 0.00414 & -0.0072 & 0.0155 \\
\hline D 10 before & 0.996 & 26 & 0.328 & 0.00578 & -0.0061 & 0.0177 \\
\hline D 9 before & 0.172 & 26 & 0.865 & 0.00060 & -0.0066 & 0.0078 \\
\hline D 8 before & -0.589 & 26 & 0.561 & -0.00168 & -0.0075 & 0.0042 \\
\hline D 7 before & -0.762 & 26 & 0.453 & -0.00329 & -0.0122 & 0.0056 \\
\hline D 6 before & 0.783 & 26 & 0.441 & 0.00377 & -0.0061 & 0.0137 \\
\hline D 5 before & 0.335 & 26 & 0.740 & 0.00152 & -0.0078 & 0.0108 \\
\hline D 4 before & -0.919 & 26 & 0.367 & -0.00329 & -0.0107 & 0.0041 \\
\hline D 3 before & -0.170 & 26 & 0.866 & -0.00052 & $\begin{array}{l}-0.0068 \\
\end{array}$ & 0.0058 \\
\hline D 2 before & -1.606 & 26 & 0.120 & -0.01173 & -0.0267 & 0.0033 \\
\hline D 1 before & -0.800 & 26 & 0.431 & -0.00424 & $\begin{array}{l}-0.0151 \\
\end{array}$ & 0.0067 \\
\hline D 0 & -1.458 & 26 & 0.157 & -0.03587 & -0.0864 & 0.0147 \\
\hline D 1 & -1.450 & 26 & 0.159 & -0.02621 & -0.0634 & 0.0109 \\
\hline D 2 & -1.057 & 26 & 0.300 & -0.00970 & -0.0286 & 0.0092 \\
\hline D 3 & 1.204 & 26 & 0.239 & 0.01166 & -0.0082 & 0.0316 \\
\hline D 4 & 0.453 & 26 & 0.654 & 0.00488 & -0.0172 & 0.0270 \\
\hline D 5 & -0.794 & 26 & 0.435 & -0.00481 & -0.0173 & 0.0076 \\
\hline D 6 & -1.214 & 26 & 0.236 & -0.00755 & -0.0203 & 0.0052 \\
\hline D 7 & 0.283 & 26 & 0.780 & 0.00106 & -0.0066 & 0.0088 \\
\hline D 8 & -0.831 & 26 & 0.413 & -0.00344 & -0.0119 & 0.0051 \\
\hline D 9 & -1.451 & 26 & 0.159 & -0.01310 & -0.0316 & 0.0055 \\
\hline D 10 & -0.842 & 26 & 0.407 & -0.01101 & -0.0379 & 0.0159 \\
\hline D 11 & -0.448 & 26 & 0.658 & -0.00128 & -0.0072 & 0.0046 \\
\hline D 12 & 0.421 & 26 & 0.677 & 0.00175 & -0.0068 & 0.0103 \\
\hline D 13 & 0.887 & 26 & 0.383 & 0.00295 & -0.0039 & 0.0098 \\
\hline D 14 & -0.002 & 26 & 0.999 & -0.00001 & -0.0098 & 0.0098 \\
\hline D 15 & 0.183 & 26 & 0.856 & 0.00055 & -0.0057 & 0.0068 \\
\hline D 16 & -0.156 & 26 & 0.877 & -0.00052 & -0.0073 & 0.0063 \\
\hline D 17 & 1.087 & 26 & 0.287 & 0.00471 & $\begin{array}{l}-0.0042 \\
\end{array}$ & 0.0136 \\
\hline D 18 & 0.180 & 26 & 0.859 & 0.00072 & -0.0075 & 0.0090 \\
\hline D 19 & 0.602 & 26 & 0.552 & 0.00319 & $\begin{array}{l}-0.0077 \\
\end{array}$ & 0.0141 \\
\hline
\end{tabular}




\begin{tabular}{|l|l|l|l|l|l|l|}
\hline D 20 & 1.027 & 26 & 0.314 & 0.01196 & -0.0120 & 0.0359 \\
\hline
\end{tabular}

As Table 2 shows, in D 0 (the day of the event), an AAR of $3.59 \%$ is achieved. Of the investigated companies, only 11 were found to have a positive return during the research period. On the other hand, 16 companies had a negative return. Two companies were particularly noticeable. On the day the US Environmental Protection Agency published the manipulation of exhaust emission values, the German automobile group Volkswagen AG[25] had a share price decline of $-16.97 \%$. In the period under review, only the major British bank Barclays outperformed this sharp fall in share prices. In the wake of the Libor scandal,[26] the United States Treasury Department published a fine of \$160 million (\$ referring to USD), which caused the company to lose $17.31 \%$ of its share price. It is to be assumed that the large price losses could be related to the US justice system. In the past, companies that have committed offences have been subject to enormous fines.[27]

The data also show that even one day after the information became known, in the day D 1 , a relatively clear negative AAR of $-2.62 \%$ was achieved. The information processing activity therefore does not seem to have been entirely completed by the following day either, as Röder, among others, demonstrated in his study on price reactions to ad hoc reports, particularly for smaller second-line stocks.[28] Figure 1 shows graphically the evolution of the AARs during the research period.

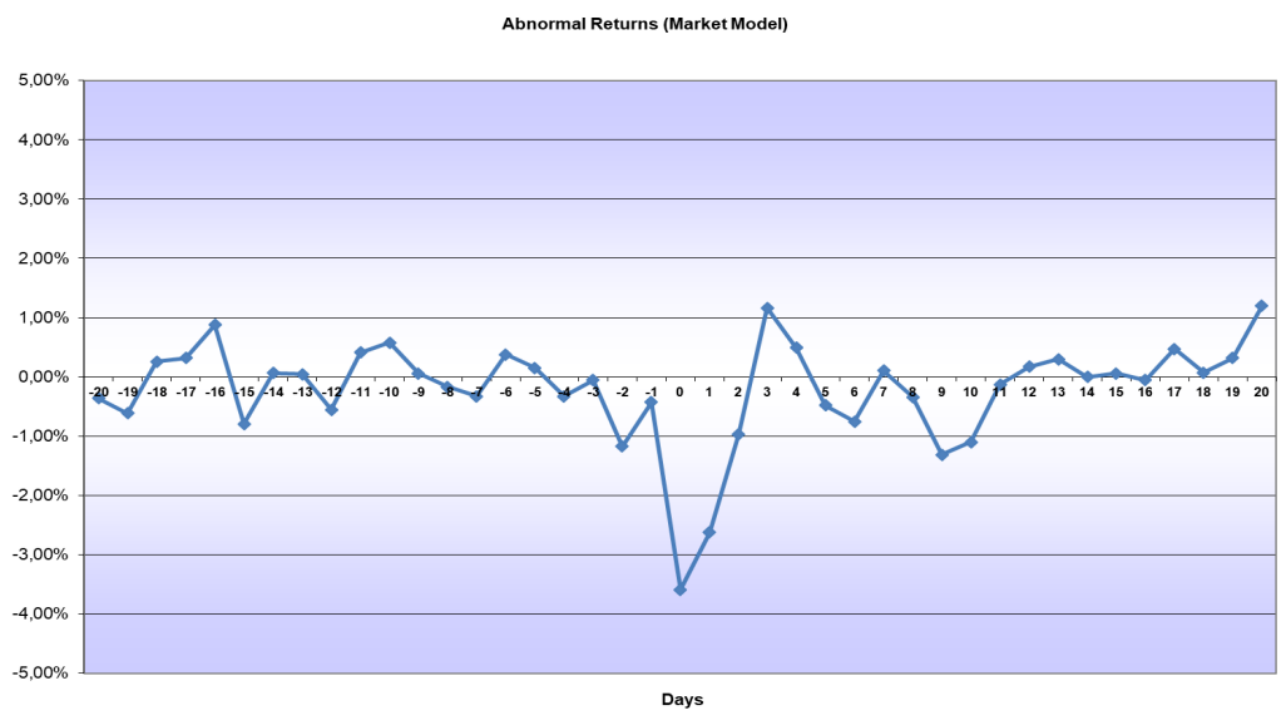

Fig. 1. Average abnormal returns (AARs) in the event window [-20;20]. (Source: Own Representation).

If the AARs from $t_{-20}$ on are added up over the event period starting on the day the cumulative abnormal returns are obtained. They are only slightly different from zero at the beginning of the research period, but are constantly positive. Figure 1 shows the development of cumulative abnormal returns.

Apart from the slightly negative CAR in the week before the information publication, in $\mathrm{t}_{0}$ (the event day), a strongly negative cumulative abnormal return of $-3.58 \%$ is realized. A day later, the CAR rises again, but still stands at $2.62 \%$. However, yields rise to $1.1 \%$ on day 3 and peak at $1.3 \%$ on day 9 . This suggests that specialized investment funds are sensing the opportunity to acquire shares in the scandalous company at a favorable price as a result of the slump in share prices. VW alone has since then reached a price of around 150 euros again, due to the scandal and the low share price of almost 100 euros (as at 06/29/2018). This 
corresponds to a relative annual return of $13.23 \%$, provided that investors were able to acquire and sell shares at the stated values.

Cumulative Abnormal Returns (Market Model)

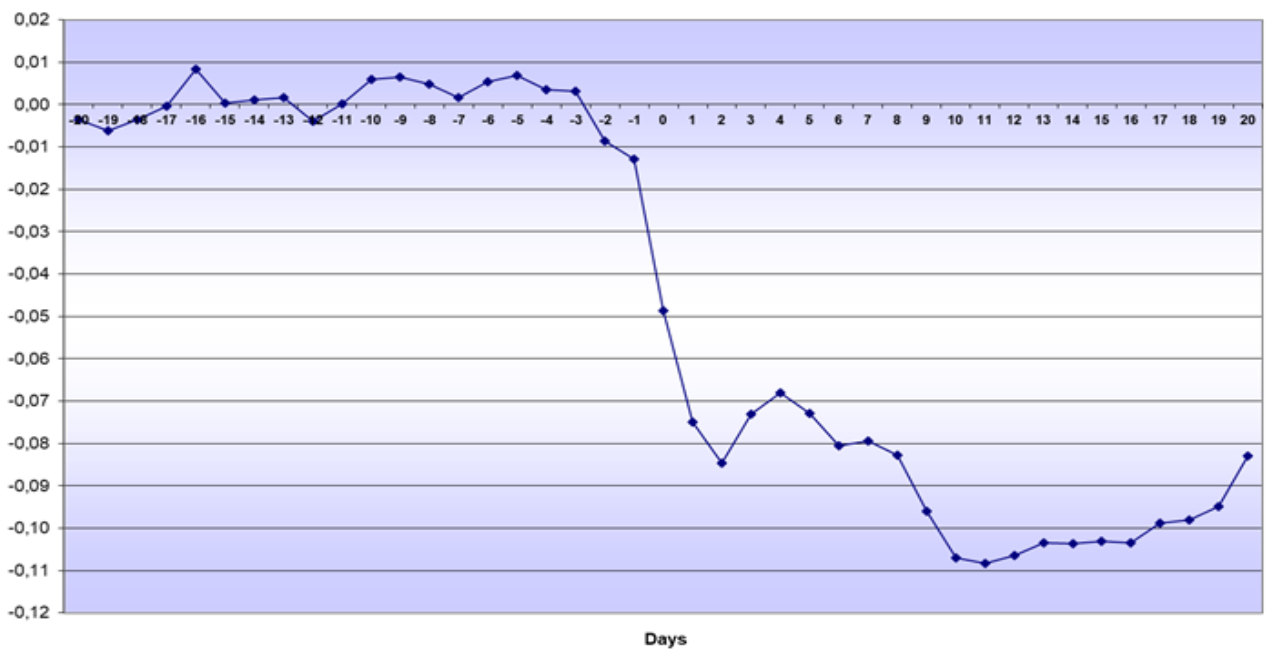

Fig. 2. Cumulated Abnormal Returns (CAR) in Event Window [-20;20]. (Source: Own representation).

Even in the weeks before the day of the event, sudden changes in abnormal yields can be detected. The strongest rash then occurs on the day $\mathrm{t}_{0}$, caused by the publication of scandals, fines, or other events that cause damage to the company and future. This example shows that accusations of immoral or illegal actions alone are sufficient to put pressure on a company's share price.

On the basis of the findings obtained so far, the period under investigation will be narrowed down in the following and the cumulative abnormal returns in selected periods will be examined. For this purpose, the developments in a period of twenty, ten, five, two days, and one day before and after the event day D 0 are considered. The results of the t-test are presented in Table 3.

Table 3. One-Sample Test. Statistics of cumulative abnormal returns. (Source: Own representation).

\begin{tabular}{|c|c|c|c|c|c|c|}
\hline \multirow{3}{*}{ Days } & \multicolumn{6}{|c|}{ Test Value $=0$} \\
\hline & \multirow[t]{2}{*}{$\mathbf{t}$} & \multirow[t]{2}{*}{ df } & \multirow[t]{2}{*}{$\begin{array}{l}\text { Sig. (2- } \\
\text { tailed) }\end{array}$} & \multirow[t]{2}{*}{$\begin{array}{c}\text { Mean } \\
\text { Difference }\end{array}$} & \multicolumn{2}{|c|}{$\begin{array}{l}\mathbf{9 5 \%} \text { Confidence } \\
\text { Interval of the } \\
\text { Difference }\end{array}$} \\
\hline & & & & & Lower & Upper \\
\hline D 20 around & -1.610 & 27 & 0.119 & -0.08232 & -0.1872 & 0.0226 \\
\hline D 10 around & -1.614 & 25 & 0.119 & -0.11019 & -0.2508 & 0.0304 \\
\hline D 5 around & -1.861 & 25 & 0.075 & -0.07989 & -0.1683 & 0.0085 \\
\hline D 2 around & -1.620 & 25 & 0.118 & -0.08995 & -0.2043 & 0.0244 \\
\hline D 1 around & -1.510 & 25 & 0.144 & -0.06775 & -0.1602 & 0.0247 \\
\hline
\end{tabular}

It should be noted that the average CAR for all periods is negative. Although negative CARs between -6.78 and -11.02 are always achieved during the different study periods, these results are not significant at a significance level of $5 \%$.

Therefore, the hypothesis that the disclosure of immoral actions by companies is associated with a negative announcement effect cannot be confirmed. The impressive swings 
on the day of the event are due to a few outliers that have a strong negative impact on the average abnormal returns.

However, the question arises as to whether this insight can be used within the framework of an active portfolio strategy. As can be seen from the example of Bayer AG, the disclosure of immoral conduct does not necessarily imply a slump in the price of the stock concerned. When it became known on 12/16/2015 that lawsuits are now being heard in court in Germany because of the birth control pill scandal, the share price nevertheless rose by $3.86 \%$ the following day.

\section{Discussion and Conclusion}

Market critics cite numerous ethical problems to demonstrate that market outcomes are always ethically inferior and unfair. The decision in favor of a market economy system is not tantamount to a loss of value.[29]

The business ethicist Karl Homann summarizes this situation as follows: "Market economy and competition are an artificially established event for the benefit of the general public. Therefore, the market as such is a social event."[30] However, it should not be overlooked that in a competitive environment, one cannot rest on one's laurels but is always driven to innovation, investment, capital accumulation, and growth. The advantages of the market economy are found in small portions and widely dispersed. They often manifest themselves in ongoing product improvements, cost reductions, and many small technical innovations, so that the individual no longer even notices them. Although the economic order of the Federal Republic of Germany with its social market economy is strongly based on the ideas of liberalism, the formula "self-interest of the economic actors + market economy $=$ common good" does not seem to work out entirely. This is particularly evident in the numerous insolvencies, company collapses due to corporate scandals, and the high unemployment rate. Despite the market economy system, scarce and vital resources are wasted in manufacturing products that are anything but scarce.[30] For example, many types of cleaning and washing agents are washed onto the market. Obviously, the market economy system is in need of correction in many respects.

The research described above did not prove that the discovery of immoral actions by companies or their managers has a significant influence on the share price. However, it was possible to show that the share prices of smaller companies in particular reacted more strongly to negative reports than those of large DAX companies.

For companies, this means that sustainable entrepreneurial action becomes an economic constraint.[3] In times of the internet, 24-hour TV broadcasting, and social media, immoral behavior is immediately exposed and ethics and morality thus become a competitive factor. As globalization progresses, people are increasingly better informed about distant crisis areas, AIDS, poverty, and the misery of refugees. After all, climate change, mild winters, or the hurricane "Katrina" clearly draw the attention of the general public to the alleged perpetrators of such developments. This means that companies will continue to be confronted in the future with demands for an environmentally friendly and responsible use of natural resources and for humanitarian support for the poor by the rich. Ethical conduct is not per se an unnecessary cost block. In fact, it can even pay a double dividend in the form of a return and a clear conscience. Against this background, Warren Buffet, US investor and one of the richest men in the world, notes: "It takes twenty years to build a reputation and five minutes to ruin it. If you think about that, you will do things differently." 


\section{References}

1. Wirtschaftswoche (2007). Wirtschaftswoche.

2. Hauff, V. (1987). Unsere gemeinsame zukunft-Brundtland-bericht der weltkommission umwelt und entwicklung. Greven: Eggenkamp.

3. Köhler, S., Haderlein, A. (2007). Die neue Business-Moral: Corporate social responsibility prägt die märkte von morgen. Kelkheim (Taunus): Zukunftsinstitut, $8 \& 21$.

4. Waldkirch, R. (2005). Wirtschaftsethik der globalisierung. Tübingen: Mohr Siebeck.

5. Kreikebaum, H. (1996). Grundlagen der unternehmensethik. Stuttgart: SchäfferPoeschel.

6. Stobbe, A. (1991). Mikroökonomik. $2^{\text {nd }}$ edition, Berlin: Springer.

7. Smith, A. $(1776,1976)$. An inquiry into the nature and causes of the whealth of nations. Oxford: Clarendon Press.

8. Kirstein, R., Schmidtchen, D. (2000). Wie die „unsichtbare Hand“ funktioniert gewinnmaximierung als triebfeder der effizienz / ein „classroom-experiment“. Magazin Forschung, 1, 57-62.

9. Smith, V. (1982). Markets as economizers of information: experimental examination of the "Hayek Hypothesis". Economic Inquiry, 20(2), 165-179.

10. Enste, D. (2006). Marktwirtschaft und moral - eine ordnungsethische reflexion. Cologne: Deutscher Instituts-Verlag, 4.

11. Institut für Demoskopie Allensbach (2004). Berufsprestigeskala. Allensbach.

12. Fisher, L. (2004). How dell got soul. Strategy+Business, 36, 46-59.

13. Mulcahy, A. (2004). Keynote address. Annual Conference of Business for Social Responsibility. New York.

14. Prince, C. (2004). For citigroup, scandal in japan shows danger of global sprawl. Wall Street Journal, December.

15. Fama, E., Fisher, L., Jensen, M., Roll, R. (1969). The adjustment of stock prices to new information. International Economic Review, 10(1), 1-21.

16. Miller, M., Modigliani, F. (1961). Dividend policy, growth, and the valuation of shares. Journal of Business, 34(4), 411-433.

17. Coenenberg, A., Henes, F. (1995). Der Informationsgehalt der Zwischenberichtspublizität nach 44b Börsengesetz. ZfbF, 47, 969-995.

18. Gabler (2000). Gabler wirtschaftslexikon. $15^{\text {th }}$ edition, Wiesbaden: Betriebswirtschaftlicher Verlag Dr. Th. Gabler GmbH, 2170.

19. Göbel, E. (2006). Unternehmensethik - Grundlagen und praktische Umsetzung. Stuttgart: Lucius \& Lucius.

20. May, A. (1991). Zum Stand der empirischen Forschung über Informationsverarbeitung am Aktienmarkt - Ein Überblick. ZfbF, 43, 313-335.

21. Nix, P. (2006). Informationsverarbeitung in Hausse und Baisse - Eine empirische Untersuchung ereignisinduzierter Kapitalmarktreaktionen am deutschen Aktienmarkt im Zeitraum von 1997 bis 2002. Hamburg: Verlag Dr. Kovač, 238, 258-261.

22. Markowitz, H. (1991). Portfolio selection - efficient diversification of investments. $2^{\text {nd }}$ edition, Cambridge: Blackwell Publishers.

23. Baltagi, B. (2002). Econometrics. $3^{\text {rd }}$ edition. Berlin: Springer. 
24. Ball, R., Brown, P. (1968). An empirical evaluation of accounting income numbers. Journal of Accounting Research, 6(2), 159-178.

25. United States Environmental Protection Agency (2015, September 18). VW Notice of Violation, Clean Air Act. United States Environmental Protection Agency. https://www.epa.gov/sites/production/files/2015-10/documents/vw-nov-caa-09-1815.pdf

26. Criminal Division (2012, June 26). Fine notice. U.S. Department of Justice. https://www.justice.gov/iso/opa/resources/337201271017335469822.pdf

27. Censible (2017, July 20). Risky business: Top 10 corporate crackdowns. Censible. https://learn.censible.co/risky-business-top-ten-corporate-crackdowns/

28. Röder, K. (2000). Die Informationswirkung von Ad-hoc-Meldungen. ZfB, 70(5), 567-593.

29. Walter, N., Rosenschon, A. (1996). Ein plädoyer für die marktwirtschaft. Landsberg: Verlag Moderne Industrie GmbH, 12.

30. Homann, K., Blome-Drees, F. (1992). Wirtschafts- und unternehmensethik. Göttingen: Vandenhoeck \& Ruprecht. 